\title{
Plasmacytoid leukemia in seawater reared chinook salmon Oncorhynchus tshawytscha
}

\author{
M. L. Kent ${ }^{1}$, J. M. Groff ${ }^{2}$, G. S. Traxler ${ }^{1}$, J. G. Zinkl ${ }^{2}$, J. W. Bagshaw ${ }^{1}$ \\ ${ }^{1}$ Department of Fisheries and Oceans, Pacific Biological Station, Nanaimo, British Columbia, Canada V9R 5K6 \\ ${ }^{2}$ School of Veterinary Medicine, University of California, Davis, California 95616, USA
}

\begin{abstract}
A plasmacytoid leukemia was observed in chinook salmon Oncorhynchus tshawytscha reared in seawater netpens in British Columbia, Canada. The disease was first observed in market-size salmon $(2$ to $4 \mathrm{~kg}$ ) and caused high mortality at several facilities. The disease, referred to as manine anemia by fish farmers, is characterized by pallor of the gills due to anemia, enlargement of the spleen and kidney, and ascites. Some affected fish exhibited prominent bilateral exophthalmia. Histological examination revealed massive proliferation of plasmacytoid cells (plasmablasts) in the kidney interstitium, spleen, intestinal lamina propria, pancreas, liver, and heart. Fish with exophthalmos exhibited massive proliferation of the plasmablasts in the periorbital connective tissue, ocular muscles, and choroid gland. In tissue sections, the plasmacytoid cells had large, often lobate or clefted nuclei, and a moderate amount of amphophilic cytoplasm. In Giemsa imprints, cells had a smooth contour, contained a large nucleus, an intense staining cytoplasm, and in some cells a juxtanuclear hof was visible. Electron microscopy and immunohistochemistry revealed the plasmacytoid features of the proliferating cells. The cells contained a well organized, rough endoplasmic reticulum, the cisternae being distended with a lightly granular material. Immunoglobulin was detected in the cells in tissue sections with a goat antitrout immunoglobulin peroxidase stain. Although an infectious etiology (e.g. oncogenic virus) for the disease was suspected, no viruses have yet been detected by cell culture or electron microscopy.
\end{abstract}

\section{INTRODUCTION}

Commercial rearing of salmonid fishes in seawater netpens is an important and growing industry in British Columbia, Canada. Chinook salmon Oncorhynchus tshawytscha are the primary farmed species and the forecast harvest for 1989 is approximately 14000 tons. With the increase in this relatively new form of aquaculture in British Columbia and in Washington, USA, several new diseases of cultured salmonids have been reported (Kent \& Elston 1987).

An apparently new disease of pen-reared salmon, referred to as 'marine anemia' by fish farmers, caused severe losses in chinook salmon reared at several sites in British Columbia. The disease was first recognized in the fall of 1988 , when high mortality was observed in market-size fish. The disease is suggestive of leukemia, with massive infiltration of essentially all organs by immature blood cells that resemble plasmablasts. Apparently, the same disease was first observed in chinook salmon fingerlings reared in a freshwater hatchery in Washington State. Fish from this epizootic were submitted to the Registry of Tumors in Lower
Animals, Smithsonian Institute, Washington, D.C. (RTLA 1022, 1023), and the histological features of this disease were consistent with an acute granulocytic leukemia (Harshbarger 1984). Fredrickson et al. (1990) diagnosed this disease as an erythroid leukemia or erythroblastosis. Our results, however, indicate that the disease is a plasmacytoid leukemia (PL), and, henceforth, we refer to the proliferating cells as plasmablasts. Described here are the clinical, gross, and microscopic characteristics of PL of chinook salmon.

\section{MATERIALS AND METHODS}

Clinical observations and gross pathology. One seawater netpen site in Sechlet Inlet, British Columbia was selected for in-depth studies. Two year classes of chinook salmon were examined; fish introduced to netpens in the spring of 1987 (1987 fish) and fish introduced to netpens in 1988 (1988 fish). Forty-seven of the 1987 fish ( 2 to $4 \mathrm{~kg}$ ) that showed clinical signs of the disease were examined from October 1988 through May 1989. Ten affected 1988 fish (approximately $1 \mathrm{~kg}$ ) 
were examined on 3 August 1989. Fish were killed with a blow to the head.

Histology, cytology, and electron microscopy. Tissues were preserved in Davidson's solution (Humason 1979), processed for histological examination, and stained with either hematoxylin and eosin or Brown and Hopps Gram stain (Brown \& Hopps 1973). Kidney, spleen and intestinal tissues for electron microscopy were fixed in $4 \%$ glutaraldehyde in Milloning's phosphate buffer, post-fixed in $1 \% \mathrm{OsO}_{4}$, embedded in Epon plastic, sectioned, stained with lead citrate and uranyl acetate, and examined with a transmission electron microscope. Hematocrits were conducted on blood of 10 fish examined on 22 February 1989. Blood was coliecied in heparinized tubes from the caudal blood vessels, and blood smears and tissue imprints were stained with Leishman's Giemsa stain (Yasutake \& Wales 1983).

Immunoperoxidase staining for the identification of immunoglobulin in the plasmablasts was performed on paraffin sections using a direct method with peroxidase-labeled, affinity purified, goat anti-trout immunoglobulin antibody (Kirkegaard and Perry Laboratories, Inc, Giathersburg, MD, USA). Paraffin sections were processed using standard techniques modified from Hennigar (1987). Sections were hydrated, washed 3 times in tris-buffered saline (TBS), incubated 5 min in TBS with $1 \%$ bovine serum albumin, incubated for 5 min in $1 \% \mathrm{H}_{2} \mathrm{O}_{2}$, rinsed in TBS, and incubated in the antibody solution at 1:50 for $1 \mathrm{~h}$. Antibody conjugated peroxidase was developed with diaminobenzidine (DAB) solution (10 mg DAB dissolved in $10 \mathrm{ml} 0.03 \%$ $\mathrm{H}_{2} \mathrm{O}_{2}$ ), washed with distilled water, amplified with $0.1 \% \mathrm{OsO}_{4}$. Finally, the sections were counterstained with methyl green.

Virology. Kidney, spleen, and pancreas from 24 affected fish were aseptically removed and placed in minimal essential medium (MEM) with antibiotics (penicillin at 100 units $\mathrm{ml}^{-1}$, streptomycin at $100 \mu \mathrm{g}$ $\mathrm{ml}^{-1}$ and amphotericin $\mathrm{B}$ at $0.25 \mu \mathrm{g} \mathrm{ml} \mathrm{m}^{-1}$, homogenized, maintained at $4{ }^{\circ} \mathrm{C}$ overnight and inoculated individually at 1 and $10 \%$ (w/v) on Epithelioma Papillosum Cyprini (EPC), Rainbow Trout Gonad (RTG-2), and Chinook Salmon Embryo (CHSE-214) cell lines using standard techniques (Amos 1985, Wolf 1988). Tissue cultures were incubated at $10^{\circ} \mathrm{C}$ for $2 \mathrm{wk}$, blind-passed and incubated for an additional $2 \mathrm{wk}$.

Bacteriology. Inocula were obtained aseptically from the kidney and orbit of the eye from 4 of the 1987 fish exhibiting characteristic features of the disease. Inocula were cultured at room temperature and at $15^{\circ} \mathrm{C}$ on sheep blood agar and Tryptic Soy Agar (Difco). Bacterial kidney disease, caused by Renibacterium salmoninarum, was observed in the same populations affected with PL. Therefore, kidneys were also cultured especially for the isolation of $R$. salmoninarum. The kidneys of one of the 1987 fish and 6 of the 1988 fish with no macloscopic or histological signs of $R$. salmoninarum infection were cultured on KDM-2 using the sensitive nurse culture technique (Evelyn et al. 1989). Gram stains were prepared from kidney imprints.

\section{RESULTS}

\section{Clinical and gross pathology}

Plasmacytoid leukemia was observed at 6 sites in the Sechelt area, British Columbia, in the fall of 1988 through to the spring of 1989 . The disease was first observed in the fall of 1988 in market-size fish (2 to $4 \mathrm{~kg}$ ) that were introduced to seawater in the spring of 1987. Fish farmers observed fish from the 1988 stock with clinical signs of the disease in the spring of 1989 , and the disease was confirmed in this stock by histology in August 1989. At the primary study site, PL caused approximately $50 \%$ mortality in 1987 fish during the fall and the winter of 1988-1989. By November 1989, similar losses occurred in the 1988 fish, amounting to approximately 46000 fish.

Affected fish were dark, lethargic, and swam near the surface. Pallor of the gills, indicating anemia, was a consistent finding. Approximately $20 \%$ of fish with PL exhibited severe bilateral exophthalmia (Fig. 1). Dissection of affected eyes revealed that the exophthalmos was due to a massive accumulation of hyperemic tissue in the orbit of the eye. The thymus appeared normal and, typical of adult fish, was difficult to discern within the gill chamber. Internal examination revealed renal and splenic enlargement. Severely affected kidneys were uniformly swollen, mottled, and grey. Mod-

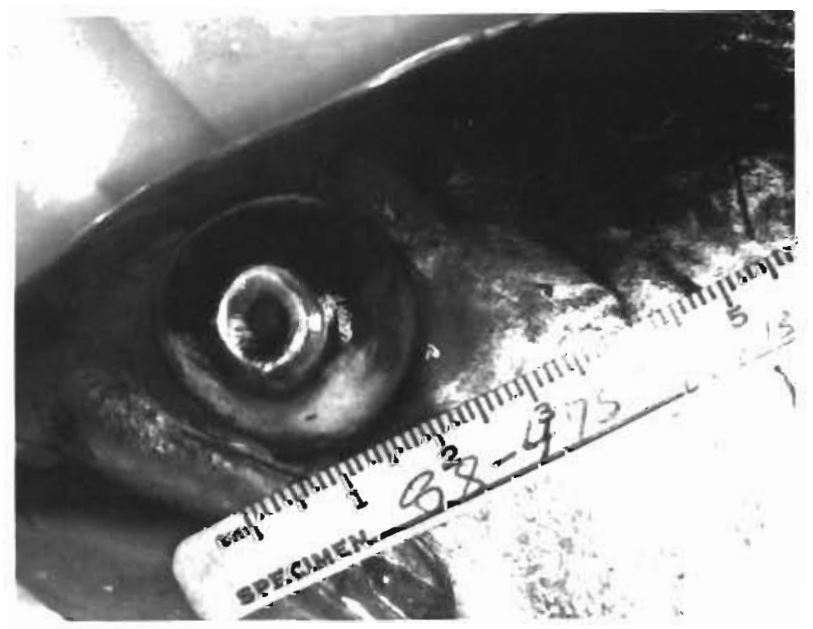

Fig. 1. Oncorhynchus tshawytscha. Exophthalmos in a chinook salmon with plasmacytoid leukemia 
erately involved kidneys were normal in color and slightly enlarged. Petechial haemorrhages occurred in the liver, mesenteric fat, pancreas, heart and skeletal muscle. The lower intestinal wall was markediy thickened. Some fish had ascites consisting of a clear or serosaguinous fluid. Hematocrits conducted on blood from affected fish from the 1987 fish ranged from 2 to $28 \%$, with a variable buffy coat.

\section{Histopathology}

The plasmablasts proliferated in essentially every tissue examined, including kidney, spleen, liver, intestine, pancreas and associated mesenteric fat, meninges, heart, skeletal muscle, skin, and eye. In the eye, there was massive infiltration of plasmablasts into the periorbital connective tissue and ocular muscles (Fig. 2).

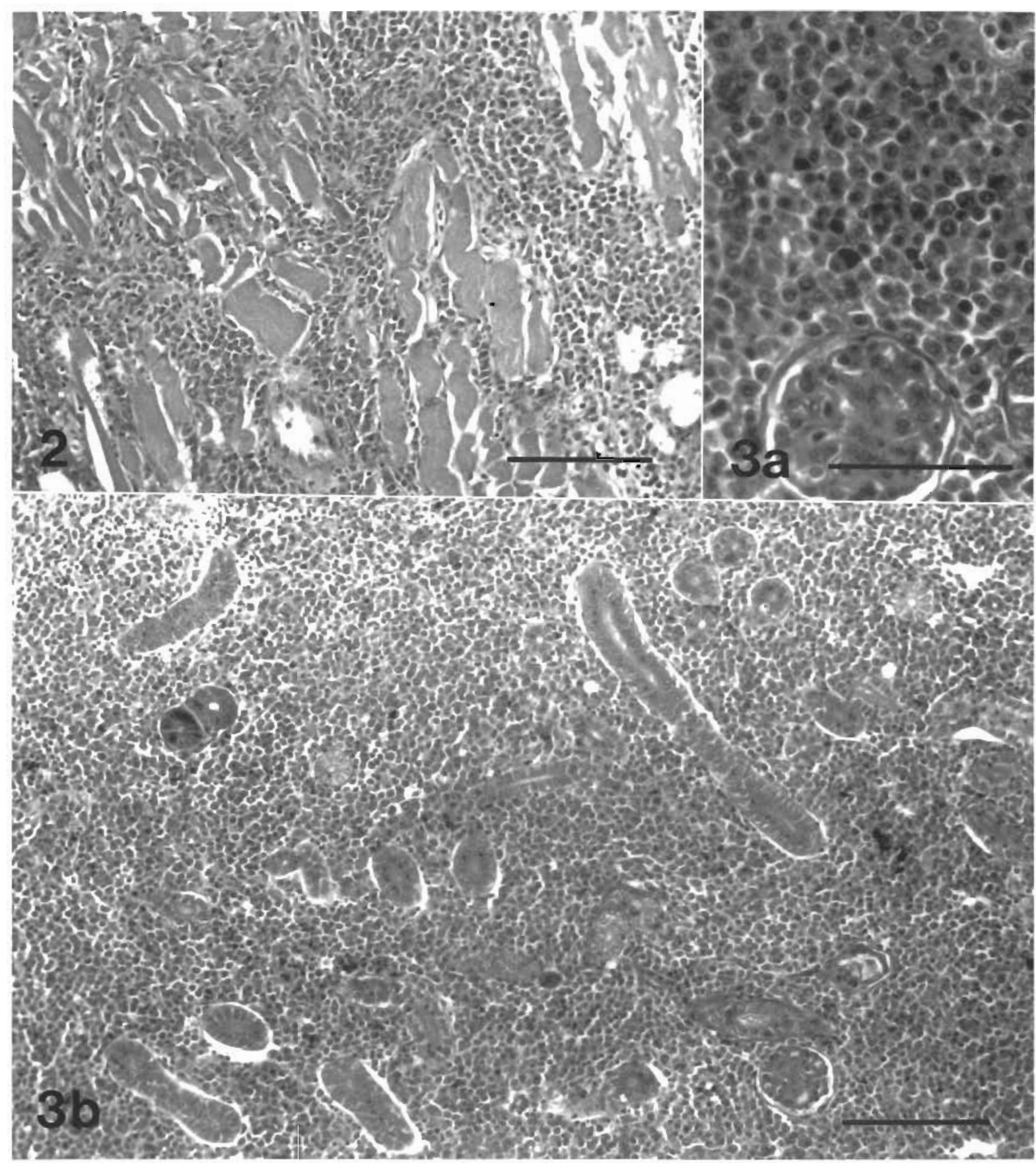

Figs. 2 and 3. Oncorhynchus tshawytscha. Tissue sections of a fish with plasmacytoid leukemia; H \& E. Fig. 2. Massive infiltration of ocular muscles by plasmacytoid cells; bar $=200 \mathrm{um}$. Fig. $3 \mathrm{a}$. Glomerulus with uniformly thickened basement membranes and abundant plasmablasts in the renal interstitium; bar $=100 \mu \mathrm{m}$. Fig. 3b. Prominent hyperplasia of plasmablasts in the renal interstitium; bar $=200 \mu \mathrm{m}$ 


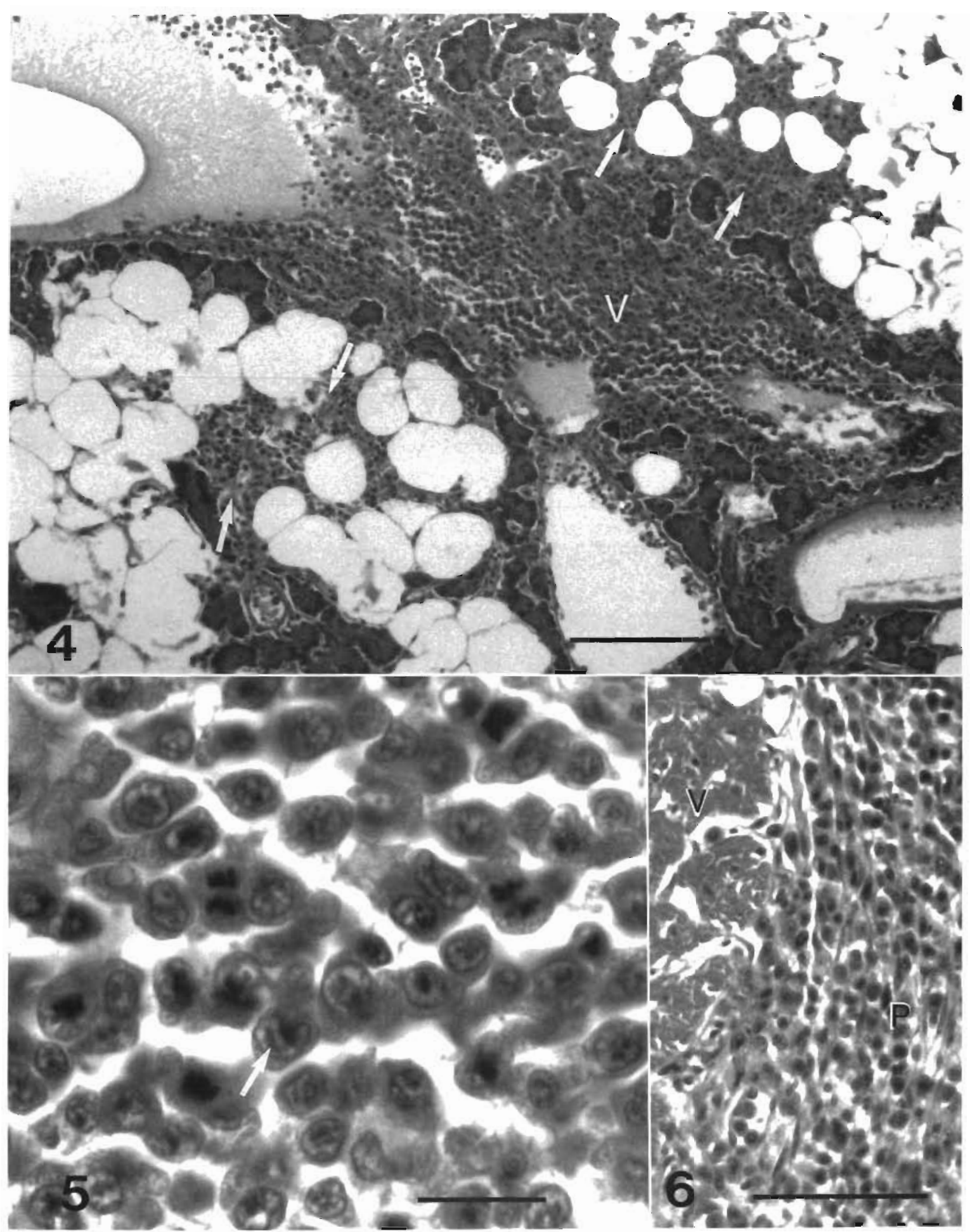

Figs. 4 to 6. Oncorhynchus tshawytscha. Tissue sections of a fish with plasmacytoid leukemia; H \& E. Fig. 4. Proliferating plasmablasts in a large pancreatic vessel ( $\mathrm{V}$ ), with invasion into the adjacent mesenteric fat (arrows); bar $=200 \mu \mathrm{m}$. Fig. 5 . High magnification of plasmablasts in a pancreatic blood vessel. Note moderate amount of finely granular cytoplasm, occasional nucleoli (arrow), and numerous mitotic figures; bar $=20 \mu \mathrm{m}$. Fig. 6 . Ventricle $(\mathrm{V}$ ) with infiltration of plasmablasts in the pericardium $(\mathrm{P})$; bar $=100 \mu \mathrm{m}$ 


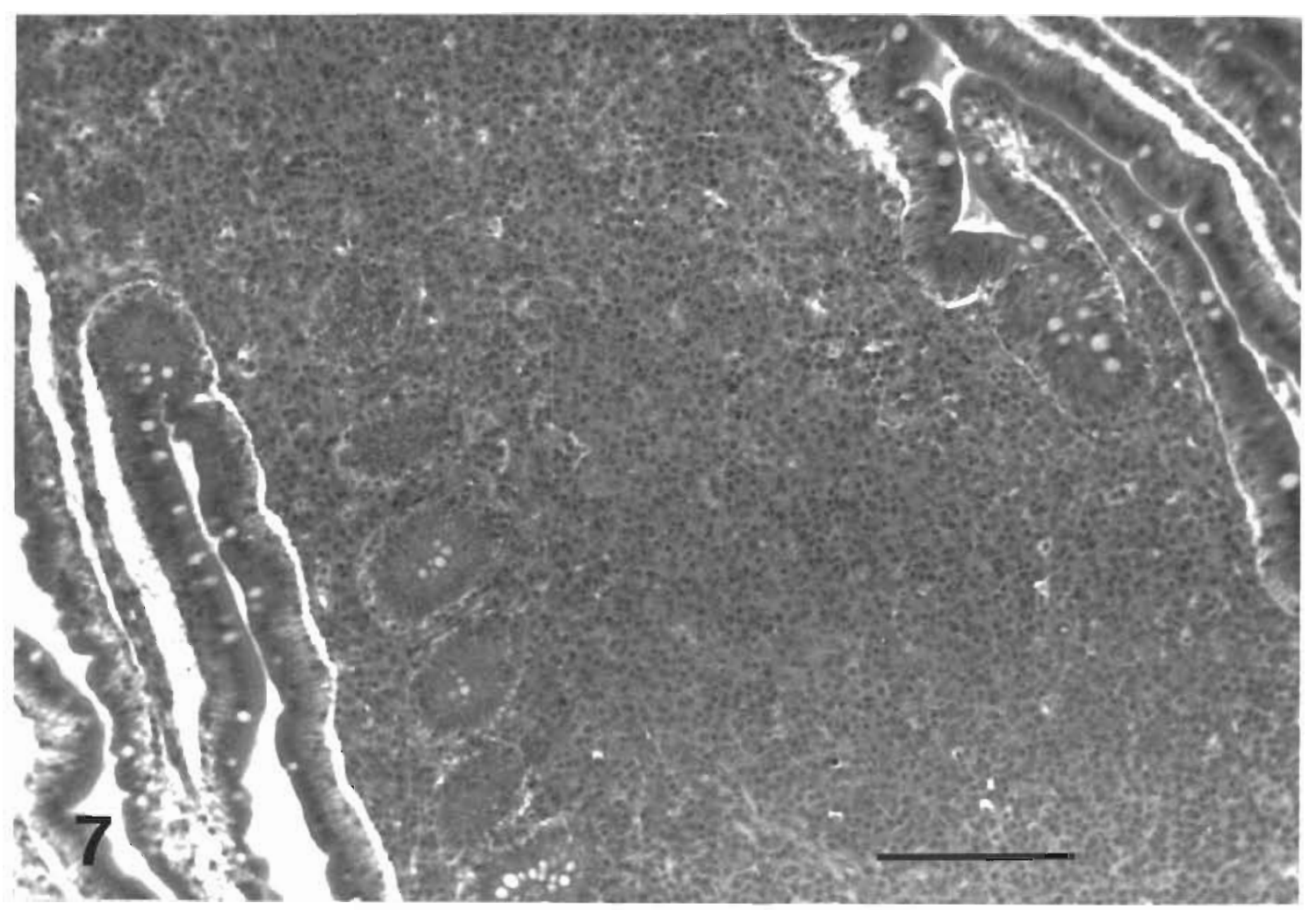

Fig. 7. Oncorhynchus tshawytscha. Expansion of an intestinal villus due to massive proliferation of plasmablasts in the lamina propria; H\& $E_{;}$bar $=200$ um

The choroid gland appeared to be the primary site of involvement in the eye; it was engorged with the plasmablasts, with vascular margination and exocytosis of the cells. The globe of the eye was intact, but often the posterior aspect of the globe was compressed due to proliferation of the plasmablasts. The comea was thickened in some fish.

Kidneys exhibited prominent hyperplasia of the interstitium due to proliferation of the plasmablasts (Fig. 3). Glomerulonephritis was often observed, and was characterized by uniformly thickened basement membranes and occasional proliferation of the epithelial cells of the Bowman's capsule. Mild erythrophagocytosis in the renal interstitium was a common finding. Small, focal granulomatous lesions with occasional necrotic cells, suggestive of bacterial kidney disease (BKD), were observed in the kidney interstitium of 28 of the 47 (53\%) 1987 fish. Gram stains revealed small Gram-positive bacilli suggestive of Renibacterium salmoninarum, the causative agent of $\mathrm{BKD}$, in these lesions. No lesions suggestive of $\mathrm{BKD}$ were detected in 1988 stock.

The plasmablasts proliferated within major blood vessels of the pancreas, and exhibited massive invasion into the surrounding tissue (Figs. 4 and 5). The spleen was generally congested and hypercellular. The hypercellularity was due to a heterogeneous population of cells, including plasmablasts. The plasmablasts occurred throughout the splenic vascular sinuses and within the splenic vessels. There was a perivascular infiltration of the plasmablasts within the liver, and the cells often proliferated within the sinusoids. Hepatocytes were usually unaffected, but some fish with severe anemia exhibited zonal hydropic degeneration of the hepatocytes.

The pericardium of the ventricle, atrium, and bulbus arteriosus of the heart was infiltrated by the plasmablasts, which formed a thick cellular capsule that surrounded the heart (Fig. 6). The cells also infiltrated the endocardium, particularly in the bulbus arteriosus, and occurred throughout the vascular sinuses of the heart.

The lower intestine was often severely affected (Fig. 7). Massive proliferation of the plasmablasts occurred in the lamina propria, and to a lesser extent in the submucosa, resulting in expansion of the intestinal villi. The intestinal epithelium was intact and appeared unaffected.

\section{Cytological characteristics, immunohistochemistry, and histopathology}

In paraffin sections, the plasmablasts contained large, often deeply clefted or lobated nuclei, and prom- 


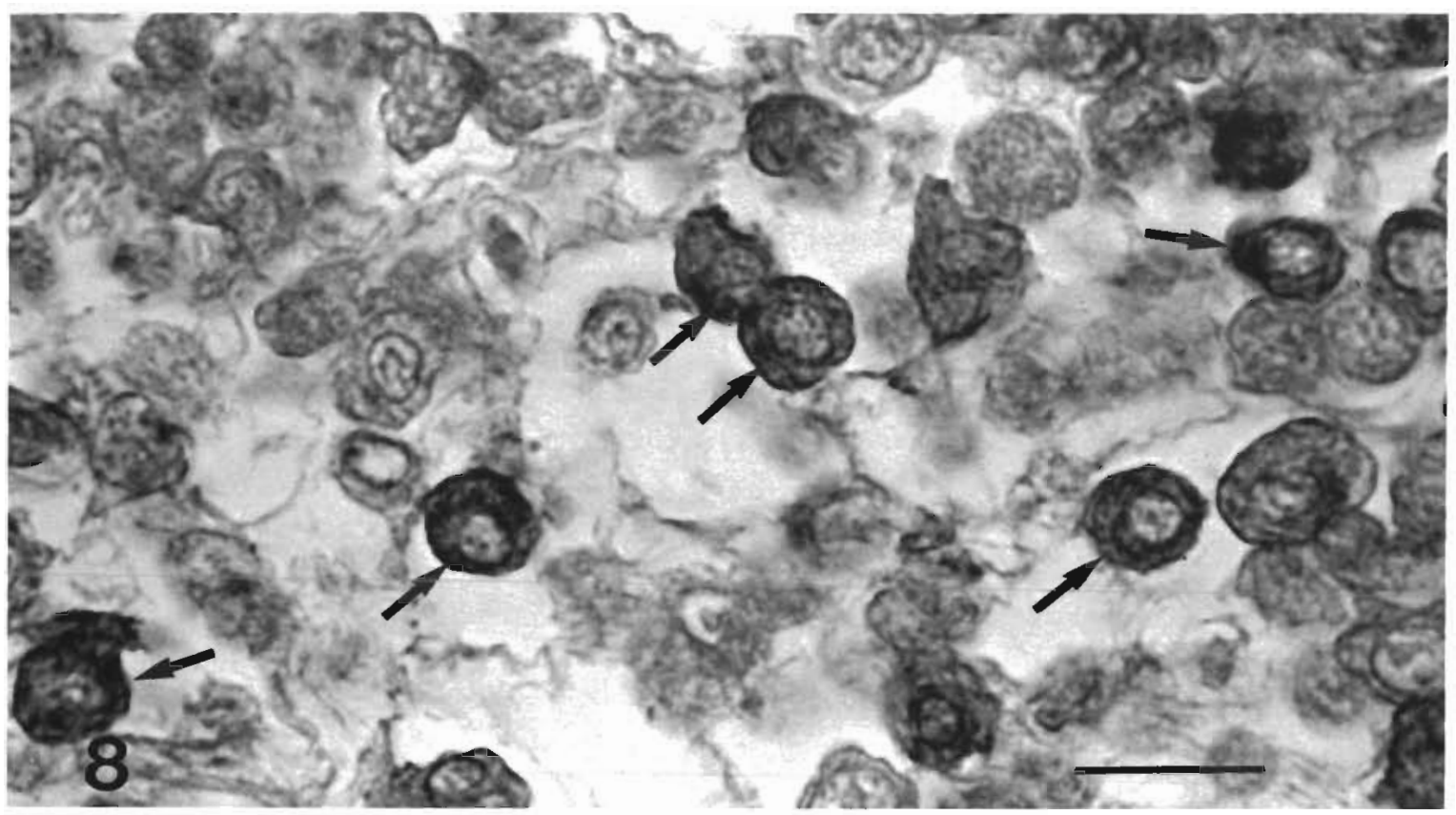

Fig. 8. Oncorhynchus tshawytscha. Plasmablasts in pancreatic mesenteries stained with peroxidase conjugated goat-anti trout immunoglobulin. Note strong positive reaction in the cytoplasm (arrows); bar $=20 \mu \mathrm{m}$

inent nucleoli. They had a moderate amount of finely granular, eosinophilic or amphophilic cytoplasm (Fig. 5). Many of these cells were mitotically active.

Sections of intestine, pancreas, and associated fat and mesenteries that were stained with the peroxidaselabeled goat anti-trout immunoglobulin revealed a strong positive reaction in the cytoplasm of 30 to $50 \%$ of plasmablasts (Fig. 8). Other cell types in these tissues were negative.

Giemsa-stained imprints of blood, visceral organs, and the eye revealed numerous plasmablasts (Figs. 9 and 10 ). The cells had a smooth contour, varied in size from 10 to $20 \mu \mathrm{m}$, and contained sparse to moderate amounts of basophilic cytoplasm. Nuclei were large, occasionally indented, and contained a smoothly homogeneous to moderately reticulated chromatin pattern. A juxtanuclear hof was observed in some cells

Electron microscopic examination of the plasmablasts in the lamina propria of the lower intestine (Figs. 11 to 13), spleen and kidney interstitium revealed an abundant, well-organized rough endoplasmic reticulum (RER). The cisternae of the RER were often dilated and contained a finely granular, electron-lucent material. A few cells exhibited severe dilation of the cisternae resulting in accumulations suggestive of Russel bodies (Fig. 12). Although evident in some cells (Fig. 12), Golgi zones were poorly differentiated in most. Nucleoli were observed in cells with less developed RER. A moderate amount of heterochromatin was dispersed in a pachychromatic pattern throughout the nucleus and often accumulated adjacent to the nuclear envelope. Some plasmablasts were seen undergoing mitosis (Fig. 13)

\section{Virology and bacteriology}

No cytopathic effect indicative of a viral etiology was observed in any of the tissue cultures. No pathogenic bacteria were isolated on blood agar or TSA from fish with PL from netpens. Gram-positive bacilli suggestive of Renibacterium salmoninarum, were observed in Gram-stained kidney imprints of fish also showing histological signs of $\mathrm{BKD}$. The bacterium was isolated from the kidney of the 1987 fish using KDM-2, whereas R. salmoninarum was not isolated from the 61988 fish with PL

\section{DISCUSSION}

Ultrastructural and immunohistochemical observations showed that the proliferating cells had affinities to plasma cells. Plasma cells in fishes are readily identified by electron microscopy and their ultrastructure is similar to that of plasma cells from higher vertebrates (Smith et al. 1970, Cenni 1984, Fänge \& Pulsford 1985. Rowely et al. 1988). Consistent with ultrastructural descriptions of plasma cells, the plasmablasts described in the present study contained a well organized ER with dilated cisternae containing lightly granular material, and a perinuclear zone occupied by the Golgi body. Moreover, immunoperoxidase staining 


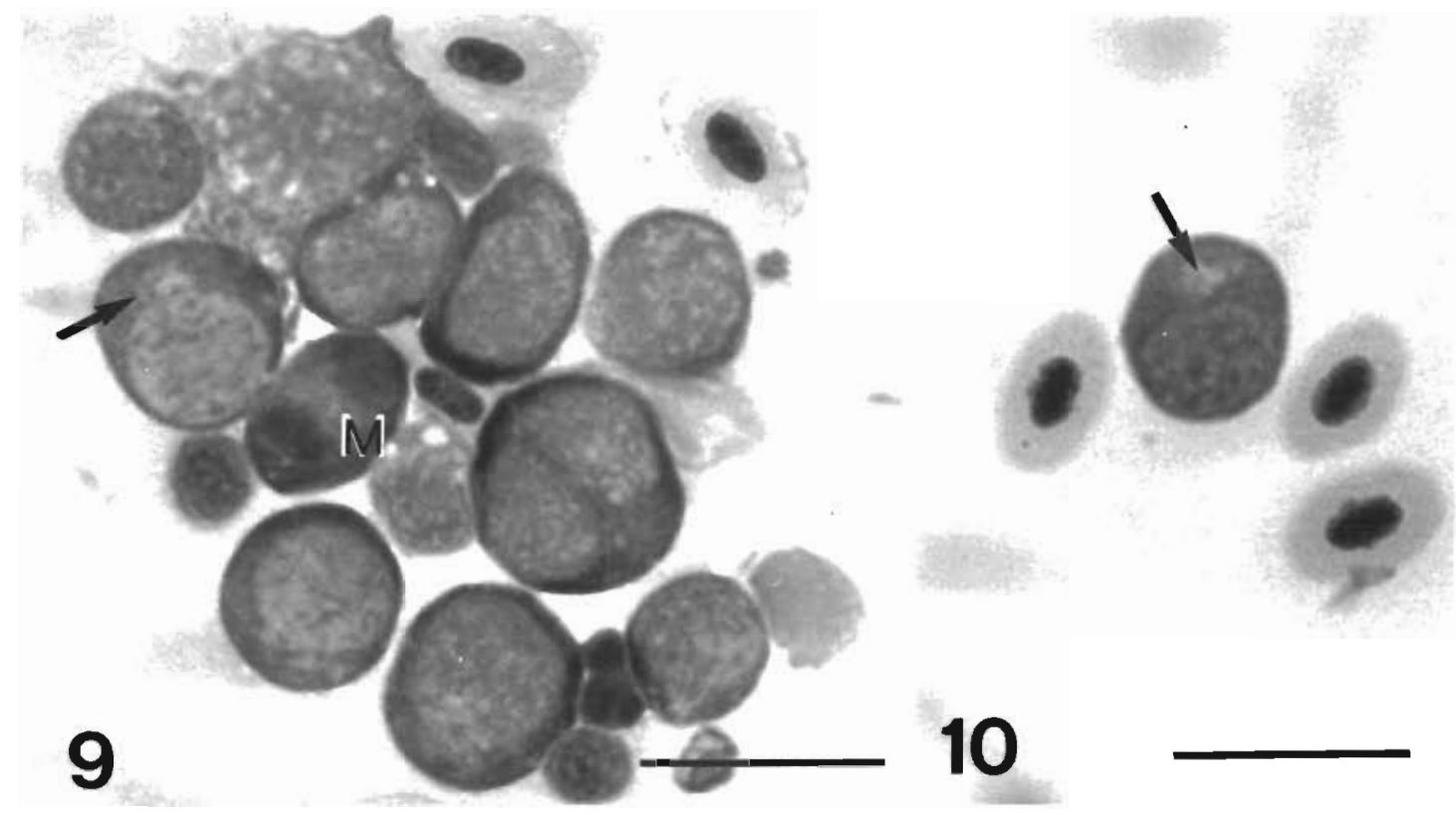

Figs. 9 and 10. Oncorhynchus tshawytscha. Giemsa imprints of plasmablasts from liver and blood. Some cells exhibited a juxtanuclear hof (arrows) or were undergoing mitosis; bar $=20 \mu \mathrm{m}$

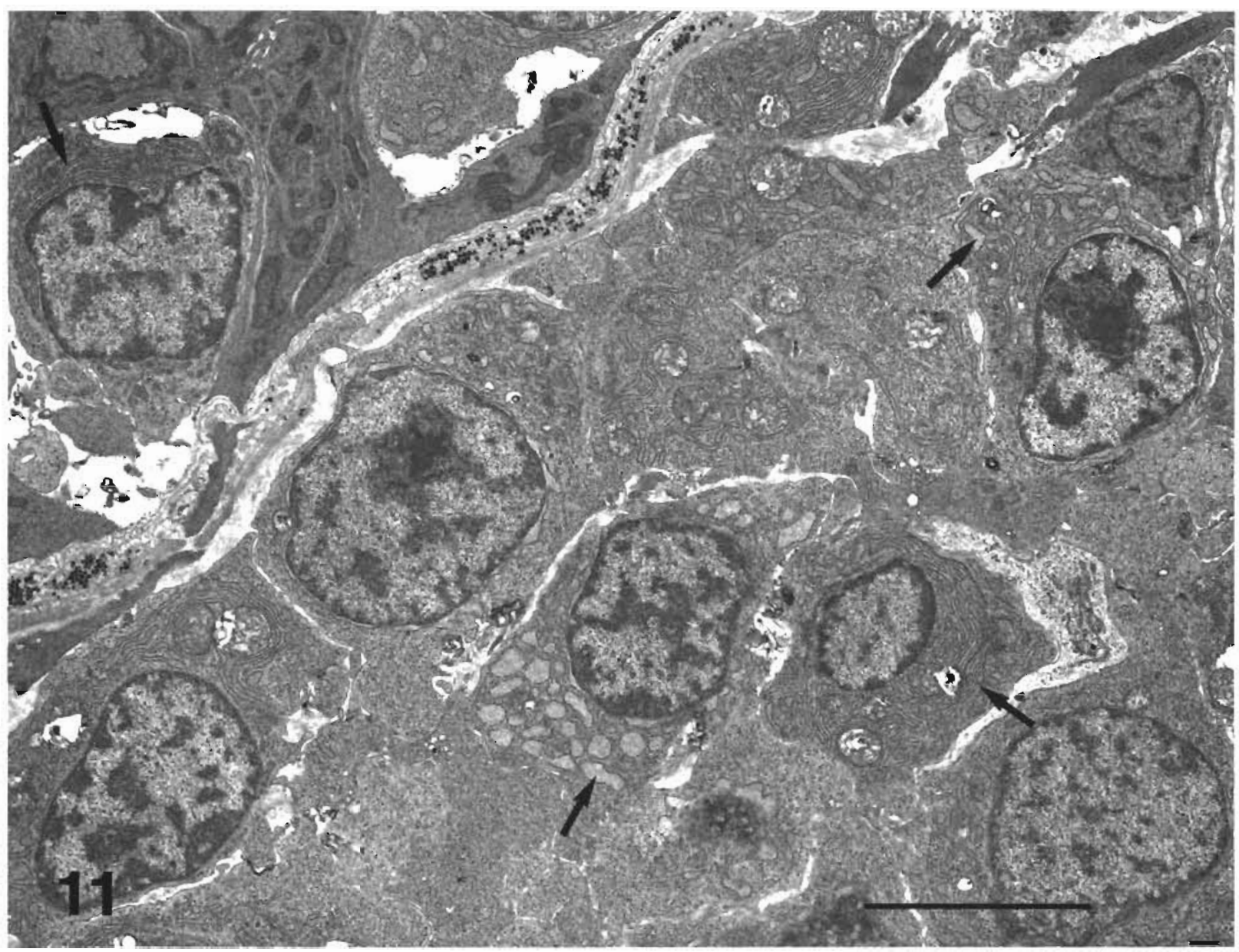

Fig. 11. Oncorhynchus tshawytscha. Electron micrograph of plasmablasts in the intestinal lamina propria. Rough endoplasmic reticulum (RER) is abundant in most plasmablasts (arrows); bar $=5 \mu \mathrm{m}$ 


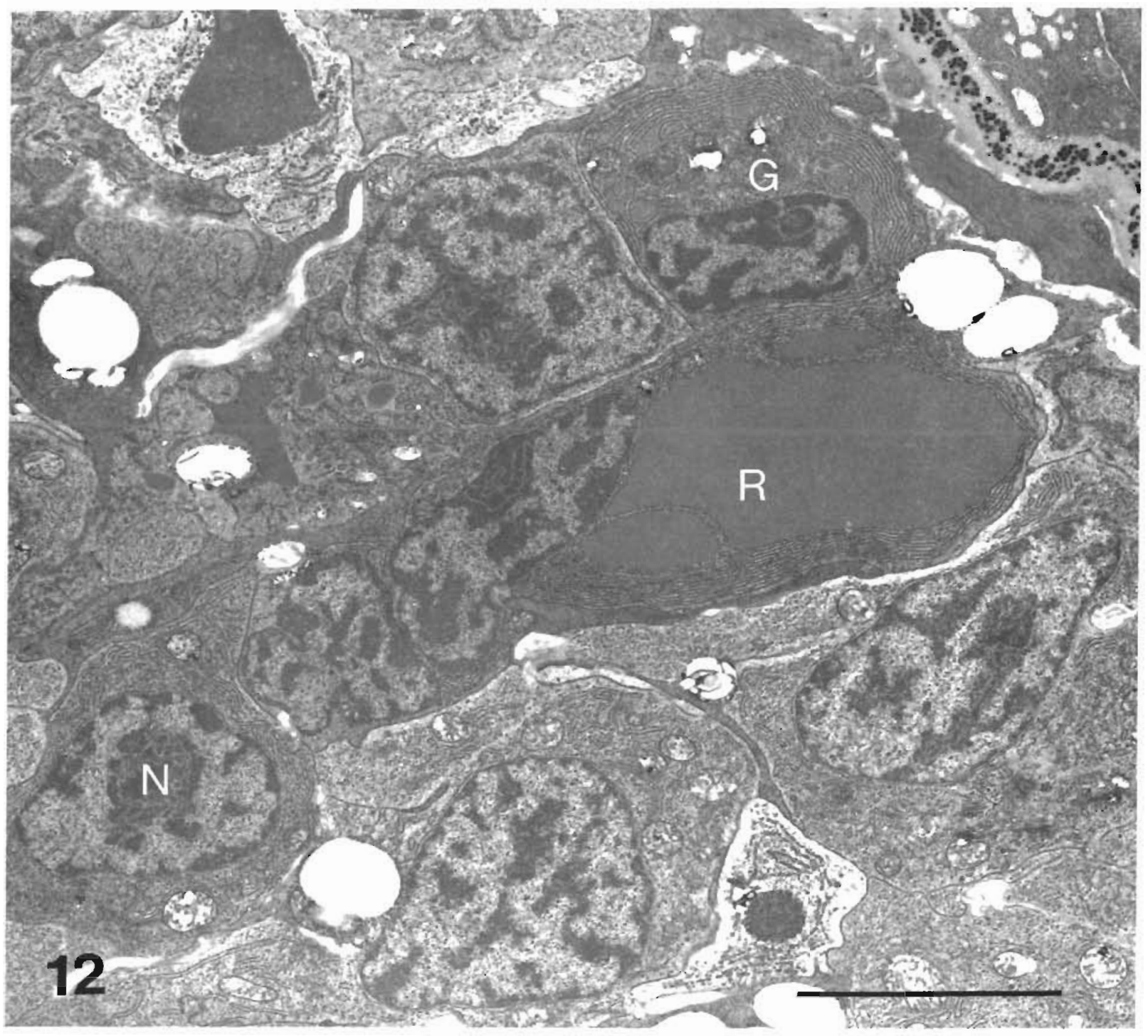

Fig 12 Oncorhynchus tshawytscha. Electron micrograph of plasmablasts in the intestinal lamina propria. Cisternae of the RER is dilated with finely granular material, resulting in the formation of a Russel body (R) in one cell. Golgi zones (G) are evident in some cells; bar $=5 \mu \mathrm{m}$

with goat ant1-trout immunoglobulin antiserum indicated the presence of .mmunoglobulin in the cytoplasm of some of the plasmablasts

By light microscopy, plasma cells are infrequently observed or recognized in teleost fishes (Rowely et al 1988) This may be due in part to the absence of a distinct 'cart-wheel' nucleus (Smith et al 1970), as described in plasma cells of higher vertebrates The plasmablasts in the present study did not exhibit distinctive plasma cell features by light microscopy, asıde from the juxtanuclear hot seen in some cells in imprints. This may account for the diagnoses of granulocytic or erythroid leukemia for the apparently same disease that occurred in freshwater-reared chinook salmon in Washington State (Harshbarger
1984. Frednckson et al. 1990). After review of the histological material and imprints from the Washington epizootic, we conclude that the disease in Washington State chinooks is the same as the one reported here.

Aggressive invasion and proliferation by the plasmacytoid cells in essentially every tissue, and the relative immaturty of the proliferating cells, suggests that the disease is a neoplasm rather than a reactive plasmacytosis By both light and electron microscopy, we observed many of the plasmablasts undergoing mitosis. This also suggests neoplasia because normal plasma cells are considered end-stage cells and only transtormed, neoplastic plasma cells are capable of division.

Although most hematopoietic neoplasms described in fishes have been lymphomas (Dawe 1969, Fredrick. 


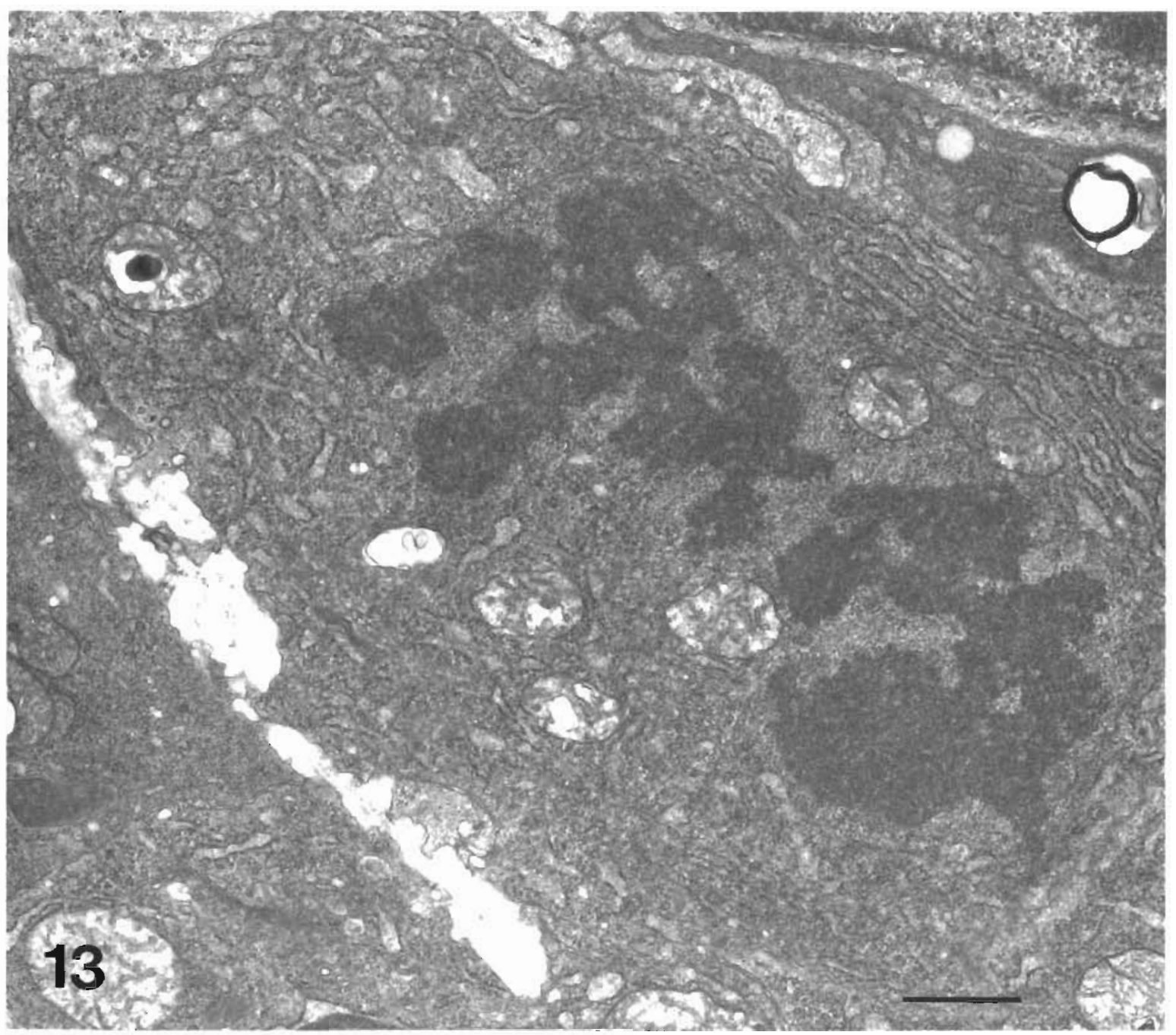

Fig. 13. Oncorhynchus tshawytscha. Electron micrograph of a plasmablast undergoing mitosis; bar $=1 \mu \mathrm{m}$

son et al. 1990), plasmacytomas have been reported from 5 species of fishes: pike Esox lucius, muskellunge E. masquinongy, channel catfish Ictalurus punctatus, small mouth bass Micropterus salmoides, and sleeper goby Oxyeleotris marmorata (Fredrickson et al. 1990). A plasma cell leukemia was observed in brown bullhead $I$. nebulosus, which was transmissible with cellfree filtrates, with onset at about $10 \mathrm{wk}$ (Sonstegard 1979. Gross 1983). A retroviral etiology was suggested for this disease because, in addition to cell-free transmission, reverse transcriptase activity was detected in affected tissues (Sonstegard 1979). A retroviral etiology has also been reported for lymphoma of pike. The lymphoma was transmitted with cell-free material (Mulcahy \& O'Leary 1970, Brown et al. 1975, Sonstegard 1976), and reverse transcriptase and C-type retroviruses were associated with the neoplasms (Papas et al, 1976).

Plasmacytoid leukemia of chinook salmon is prob- ably caused by an infectious agent e.g. an oncogenic virus. The disease was transmitted with tissue homogenates, but transmission with cell-free filtrates was equivocal (Kent et al. 1990). However, this does not exclude the possibility that PL of chinook salmon has a viral etiology. It is possible that the putative virus is cell associated, and/or that the concentration of the agent was greatly reduced by filtration, as occurs with certain retroviral induced leukemias of higher animals e.g. bovine leukosis. The epizootiological pattern of the disease, in which we observed apparent horizontal transmission between year classes at affected sites, also suggests that PL is caused by an infectious agent.

Bacterial kidney disease, caused by Renibacterium salmoninarum, is wide-spread in chinook salmon in British Columbia (Evelyn 1987), and many fish with PL exhibited concurrent $R$. salmoninarum infections. Bacterial kidney disease has also been associated with lymphosarcomas in lake trout, Salvelinus namaycush 
(c.f Ehlinger 1963). Renibacterium, therefore, may play a role in PL. Bacterial kidney disease is usually chronic in larger fish, and is characterized by multifocal, granulomatous, necrotic lesions with intracellular bacteria in mature inflammatory cells (Wood \& Yasutake 1956, Hendricks \& Leek 1975, Bruno 1986). Plasma cell neoplasms have been induced in mice with agents that evoke chronic inflammation, such as mineral oil (Potter \& MacCardle 1964, Potter 1972), Lucite borings (Merwin \& Redmond 1963), and a staphylococcal-adjuvant mixture (Potter \& Robertson 1960). The presence of bacterial antigens may be required for the proliferation of these plasmacytomas, and McIntire \& Princler (1969) reported that mineral oil injections in germ-free mice did not induce the neoplasm. Given the hiqh prevalence of $R$. salmoninarum infections in fish with PL, and its ability to induce chronic inflammation, it is possible that the bacterium may promote the proliferation of plasmablasts seen in PL. However, $R$, salmoninarum is not the primary etiological agent of PL because PL was induced in the absence of the bacterium in laboratory transmission studies (Kent et al. 1990).

We have recently observed an intranuclear microsporidium in the plasmablasts of some fish with PL. This parasite was orginally described in anemic chinook salmon from netpens in Washington (Elston et al. 1987), and was associated with lymphoblastic proliferation in freshwater-reared chinook salmon (Morrison et al. 1990). As with $R$. salmoninarum, the role of this protozoan in PL is unclear. However, the microsporidium was not observed in either donor or recipient fish in the laboratory transmission studies (Kent et al. 1990), which indicates that it is not the primary cause of PL. As suggested by Ferguson \& Roberts (1976) for a protozoan found in a lesion resembling lymphoma in turbot Scophthalmus maximus, 'It is possible that a seperate neoplastic condition exists which provides a suitably altered environment for proliferation of the protozoa, analogous in some respects to the relationship of Burkitt's lymphoma to malarial parasites.

In conclusion, this hemic proliferative disorder of chinook salmon is apparently an infectious leukemia of the plasma cell lineage, but the etiologic agent has yet to be identified. The disease continues to be widespread in netpen-reared salmon in British Columbia, and investigations are in progress to determine its geographic distribution, host specificity, etiology, and relationship to $\mathrm{BKD}$ and the intranuclear microsporidium.

Acknowledgements. We thank Drs I Fredrickson, J. Harshbarger, C. Smith, and T. Yasutake for assistance with histological and cytological interpretations, R. Munn for electron microscopy, I. Velji and S. Raverty for assistance with immunohistochemistry, G. Prosperi-Porta for bacteriological analysis, L. Margolis and I. Evelyn for manuscript review, and the fish farmers of British Columbia, and their fish health support personnel, for assistance with collecting samples.

\section{LITERATURE CITED}

Amos, K. H. (1985). Procedures for the detection and identification of certain fish pathogens. Am. Fish Soc. Fish Health Sec. Corvallis, Oregon

Brown, E. R., Keith, L., Hazdra, J. J., Arndt, T (1975). Tumors in fish caught in polluted waters: possible explanations. In: Ito, Y., Dutcher, R. M. (eds.) Comparative Leukemia Research 1973, Leukemogenesis. Univ. Tokyo Press, Tokyo, p. 47-57

Brown, R. C., Hopps, H. C. (1973). Staining of bacteria in tissue sections; a reliable Gram stain method. Am. J. clin. Pathol. 60: 234-240

Bruno, D. W. (i986). Histopatholugy of bacterial kidncy dis ease in laboratory infected rainbow trout, Salmo gairdneri Richardson, and Atlantic salmon, Salmo salar L., with reference to naturally infected fish. J. Fish Dis. 9: 523-537

Cenni, P. (1984). The ultrastructure of leucocytes in carp (Cyprinus carpio). J. Zool., Lond. 204: 509-520

Dawe, C. J. (1969). Neoplasms of blood cell origin in poikilothermic animals. A review $w_{i}$ in Lingeman and Garner Comparative morphology of hematopoietic neoplasms. Nat cancer. Inst. Monogr 32: 7-28

Ehlinger, N. F. (1963). Kidney disease in lake trout complicated by lymphosarcoma. Prog. Fish Cult. 25: 3-7

Elston., R. A., Kent, M. L. and Harrell, L. H. (1987). An intranuclear microsporidium associated with acute anemia in the chinook salmon, Oncorhynchus tshawytscha. J. Protozool $34: 274-277$

Evelyn, T P. T (1987). Bacterial kidney disease in British Columbia, Canada: comments on its epizootioloy and on methods for its control on fish farms. In: AQUA NOR 87 Tronheim Internatl. Conf., Norske Fiskeoppdretternes Forening-Fiskeoppdretternes Salgslag A/L, Troheim, Norway, p. 51-57

Evelyn, T P. T., Bell, G. R., Prosperi-Porta, L., Ketcheson, J. E. (1989). A simple technique for accelerating the growth of the kidney disease bacterium Renibacterium salmoninarum on a commonly used culture medium (KDM2) Dis aquat. org. 7: 231-234

Fänge, R., Pulsford, A. (1985). The thymus of the angler fish, Lophius piscatorius (Pisces: Teleostei) a light and electron microscopic study. In: Manning, M. J., Tatner, M. F. (eds.) Fish immunology. Academic Press, London, p. 293-311

Ferguson, H. W., Roberts, R. J. (1976). A condition simulating lymphoma, associated with sporozoan infection in cultured turbot (Scophthalmus maximus L.). Prog. exp. Tumor Res. 20: $212-216$

Fredrickson, T. N., Walsh, A. H., Wolke, R. E. (1990). Tumors of the lymphoid and other hemopoietic tissues. In: Dawe, C., Harshbarger, J. C., Wellings, S. R., Strandburg, J (eds.) Pathobiology of spontaneous and induced neoplasms in fishes: morphology, comparative characterization and literature. Academic Press, New York (in press)

Gross, L. (1983). Tumors, leukemia and lymphosarcomas in fish. In: Gross, L. (ed.) Oncogenic viruses. 3rd edn. Pergamon Press, Elmsford, New York, p. 103-116

Harshbager, J. C. (1984). Pseudoneoplasms in ectothermic animals. Nat. Cancer Inst. Monogr 65: 251-273

Hendricks, J. D., Leek, S. L. (1975). Kidney disease postorbital lesions in spring salmon (Oncorhynchus tshawytscha). Trans. Am. Fish. Soc. 104: 805-807 
Hennigar, G. R. (1987). Techniques in nephropathology. In: Spicer, S. S. (ed.) Histochemistry in pathologic diagnosis. Marcel Dekker, Inc., New York, p. 523-524

Humason, G. L. (1979). Animal tissue techniques. W. H. Freeman Co., San Francisco

Kent, M. L., Bagshaw, J. W. Dawe, S. C. (1990). Experimental transmission of a plasmacytoid leukemia of chinook salmon Oncorhynchus tshawytscha. Cancer Res. spec. suppl. (in Press)

Kent, M. L., Elston, R. A. (1987). Diseases of seawater reared salmon in Washington State. In: Keller, S. (ed.) Proc. 4th Alaska Aquaculture Conf. No. 88-4. Alaska Seagrant College Program, Fairbanks, p. 61-63

McIntire, K. R., Princler, G. L. (1969). Prolonged adjuvant stimulation in germ-free BALB/c mice. Development of plasma cell neoplasia. Immunology 17: 481-487

Merwin, R. M., Redmon, L. W. (1963). Induction of plasma cell tumors and sarcoma in mice by diffusion chambers placed in the peritoneal cavity. J. nat. Cancer Inst. 31 997-1017

Morrison, J. M., MacConnell, E., Chapman, P. F., Westgard, R L. (1990). A microsporidium induced lymphoblastosis in chinook salmon, Oncorhynchus tshawytscha, in fresh water. Dis. aquat Org. (in press)

Mulcahy, M. F., O'Leary, A. (1970). Cell-free transmission of lymphosarcoma in the Northern pike Esox lucius L. (Pisces; Esocidae). Experientia 26: 891

Papas, T. S., Dahlberg, J. E., Sonstegard, R. A. (1976). Type C virus in lymphosarcoma in northern pike (Esox lucius). Nature, Lond. 261: 506-508

Responsible Subject Editor Professor N. Peters, Hamburg, F. R. Germany
Potter, M. (1972). Immunoglobulin-producing tumors and myeloma proteins of mice. Physiol. Rev. 52: 631-719

Potter, M., MacCardle, R. C. (1964). Histology of developing plasma cell neoplasia induced by mineral oil in BALB/C mice. J. nat. Cancer Inst. 33: 497-515

Potter, M., Robertson, C. L. (1960). Development of plasma cell neoplasms in BALB/C mice after intraperitoneal injection of paraffin-oil adjuvant, heat-killed staphylococcus mixtures. J. nat. Cancer Inst. 25: 847-861

Rowely, A. F., Hunt, T. C., Page, M., Mainwaring, G. (1988). Fish. In: Rowley, A. F, Ratcliffe N. A. (eds.) Vertebrate blood cells. Cambridge University Press, New York, p. 19-128

Smith, A. M., Wivel, N. A., Potter, M. (1970). Plasmacytopoiesis in the pronephros of the carp (Cyprinus carpio). Anat. Rec. 167: $351-370$

Sonstegrad, R. A. (1976). Studies of the etiology and epizootiology of lymphosarcoma in Esox (Esox lucius and Esox masquinongy). Prog. exp. Tumor Res. 20: 141-155

Sonstegard, R. A. (1979). Virus associated hematopoietic neoplasia in shellfish and fish. In: Yohn, D. S., Lapin, B. A., Blakeslee, J. R. (eds.) Advance in comparative leukemia research. Elsevier North Holland, Inc., New York, p. 227

Wolf, K. (1988). Fish viruses and fish viral diseases. Cornell University Press, Ithaca, New York.

Wood, E. M. Yasutake, W T. (1956). Histopathology of kidney disease in fish. Am. J. Pathol. 32: 845-857

Yasutake, W. T., Wales, J. H. (1983). Microscopic anatomy of salmonids: an atlas. U.S. Fish Wildl. Ser. Res. Publ. 150. Washington, D.C.

Manuscript first received: January 12, 1990

Revised version accepted: April 10, 1990 